\title{
RESEARCH AND COMMUNITY SERVICE MANAGEMENT INFORMATION SYSTEM AT P3-M UNIVERSITY OF YAPIS PAPUA
}

\author{
Lasmaida Gultom ${ }^{1}$, Sitti NurAlam ${ }^{2}$, Muhammad Riandi Widiyantoro ${ }^{3}$, Salahudin Robo ${ }^{4}$ \\ ${ }_{1,2,3,4}$,Program Studi Sistem Informasi, fakultas Teknik dan Sistem Informasi, \\ Universitas Yapis Papua \\ Email: ${ }^{1}$ Lasmaidagultom882@gmail.com, ${ }^{2}$ sittinuralam@gmail.com, ${ }^{3}$ riandipasdu@ gmail.com, \\ ${ }^{4}$ salahudinrobo@gmail.com
}

\begin{tabular}{|c|c|}
\hline Article Info & ABSTRACT \\
\hline Article history: & $\begin{array}{l}\text { Improving the quality of lecturers include in Tri Darma of University, } \\
\text { they are: teaching, research and community service. These activities }\end{array}$ \\
\hline Received mm dd, yyyy & are fully managed by research and community service units or \\
\hline Revised mm dd, yyyy & institutions in each university. University of Yapis Papua has a work \\
\hline Accepted mm dd, yyyy & $\begin{array}{l}\text { unit that manages these activities, it called Pusat Penelitian dan } \\
\text { Pengabdian Masyarakat }(P 3-M) \text {, where the process of managing }\end{array}$ \\
\hline Keywords: & $\begin{array}{l}\text { research and community service activities is not yet fully integrated } \\
\text { and well-documented. This study aims to create information system of }\end{array}$ \\
\hline Sistem & activity management from P3-M unit at University of Yapis Papua. \\
\hline Informasi & This information system will be used, the management of activities \\
\hline P3-M & research and community service includes administrative data for \\
\hline Penelitian & submitting activity proposals, and reporting results. It hopes can be \\
\hline Pengabdian & $\begin{array}{l}\text { coordinated well. The methods were used waterfall as a system } \\
\text { development method, Unifield Modeling Language (UML) for system } \\
\text { design, and pieces method for problem analysis. The result of this } \\
\text { study is produce a web-based information system with several menus } \\
\text { that could help P3-M University of Yapis Papua. }\end{array}$ \\
\hline
\end{tabular}

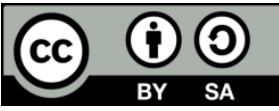

\section{Corresponding Author:}

Lasmaida Gultom

Program Studi Sistem Informasi, fakultas Teknik dan Sistem Informasi

Universitas Yapis Papua

Papua, Indonesia

Email: Lasmaidagultom882@gmail.com

(C) The Author(s) 2021

\section{Introduction}

University of Yapis Papua as higher education institution has the main task of organizing Tri Dharma university, such as Research and Community Service as inserted in Law Number 20 year 2003 concerning the National Education System which states that universities are obliged to carry out research and community service[1] . Pusat penelitian dan Pengabdian Masyarakat (P3-M) of Yapis Papua University as manage activities related to research and community service that have been or will be conducted by lecturers at Yapis Papua University.

Currently, the activities at P3-M are managing research data and community service using Office word and excel applications, and its distribution via email (electronic mail) and SMS media as information about these activities. Document recording is formatted several different files and stored in separate places. [2]. It will have a long time in making reports on research and community service. 


\subsection{Problem of the research}

From the description above, the research problem can be formulated as follows: "How to create a centralized data management system of research and community service to make it LP2M easir to coordinate data of lecturers conduct research and community service."

\section{2. objective of the research}

The research aims to design an information system for the management of research and community service activities with centralized and integrated data storage.

\subsection{Benefits of the research}

Easy manage and organize data from the results of tri dharma activities of lecturers at Yapis Papua University for LP2M.

\section{Research Method}

Information systems are a unit of several elements such as software, hardware, infrastructure and human resources to work together to achieve goals [3].

\subsection{Waterfall}

Waterfall method describes the phases of system development in a structured and systematic from the level of needs analysis, specification, design, coding, testing, implementation [4]. Each implementation is carried out sequentially as shown below;

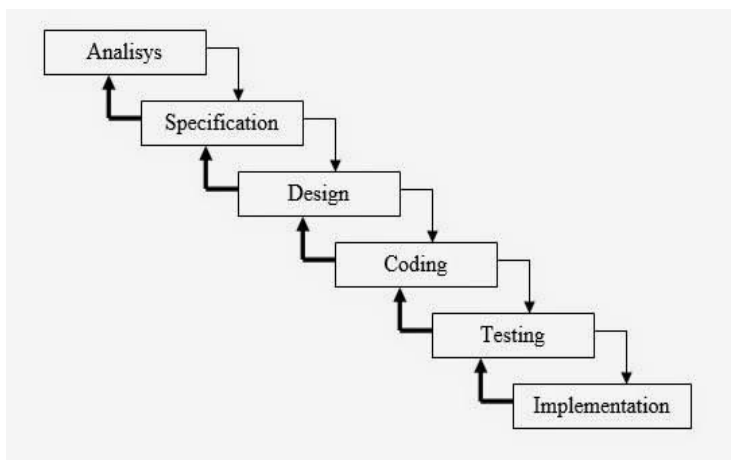

Figure 1. Waterfall Method (Hamzah, 2016)

\subsection{UML (Unified Modeling Language)}

This research used UML method in making the process flow and system design. The method of building software model using diagrams or symbols to represent system elements. The phases used are: Use Case Diagrams, Class Diagrams, Activity Diagrams and Sequence Diagrams [5].

\subsection{Data Collection Method}

Data collection methods used are as follows: firstly is observation ie. Conducting observations and reviews at P3-M Uniyap and then making the conclusions. Secondly is interview, it is question and answer process with the head of LP2M and its staff. Study of journal references from previous researchers.

\subsection{Object of research}

The place of data collection and the object of research is at LP2M Yapis University, Uniyap building, IV Floor Jln. Sam Ratulangi Doc V Jayapura.

\subsubsection{Primary data}

Data related to P3-M activities such as research proposal documents, results of community service reports and others.

\subsubsection{Secondary Data}

Supporting data such as journals related to data and processes involved in the activities of tri dharma of university [5]. 


\section{Result and Discussion}

\subsection{Use Case Diagrams}

One of the processes in design phase is the analysis of the interaction between the user and the system process [6]. The process is based on P3-M's functional requirements to describe these needs using use case diagram as the following Figure:

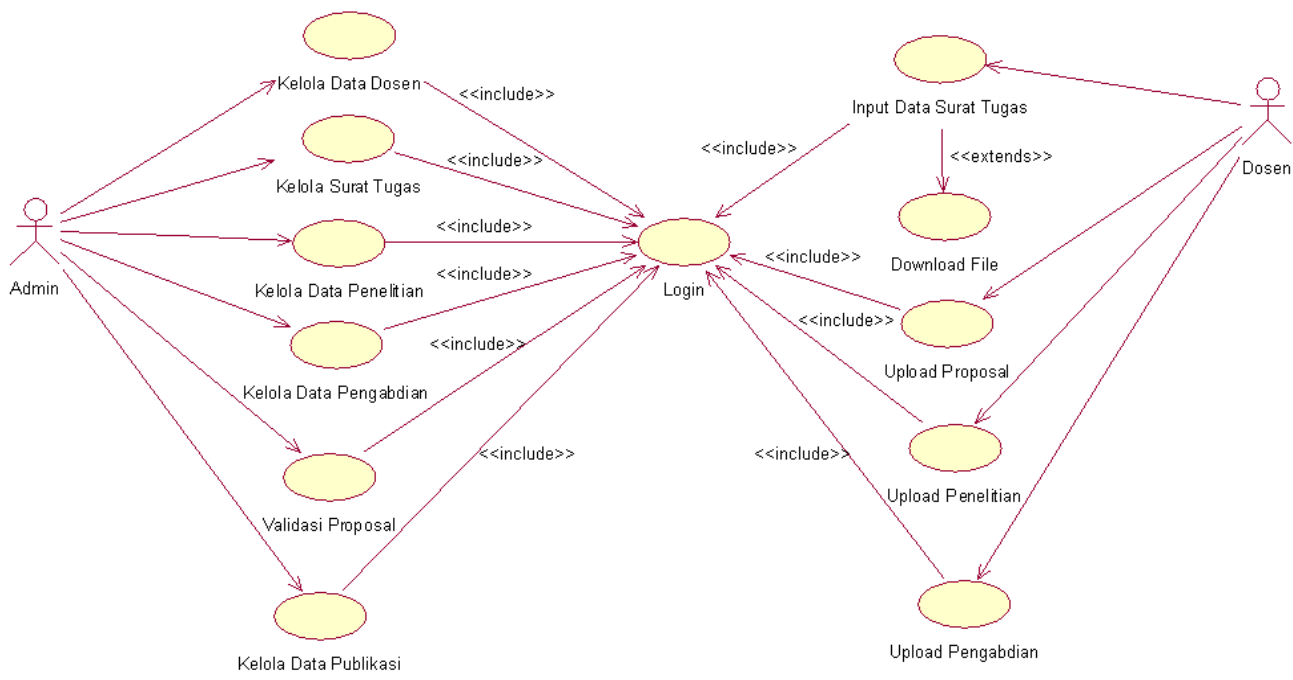

Figure 2. Use Case Diagram

From Figure 2. Explaining the actor in the design of this system are admins and lecturers. Admin tasks carry out processes such as managing lecturer data, managing assignment letters, managing research data, managing service data, validating proposals, managing publication data. The duties of the lecturer are inputting assignment letter data, downloading files, uploading proposals, uploading research, uploading community service.

\subsection{Activity Diagram}

\subsubsection{Activity Diagram of Lecturers Data Process}

Activity diagram of lecturers data process shown by the following Figure:

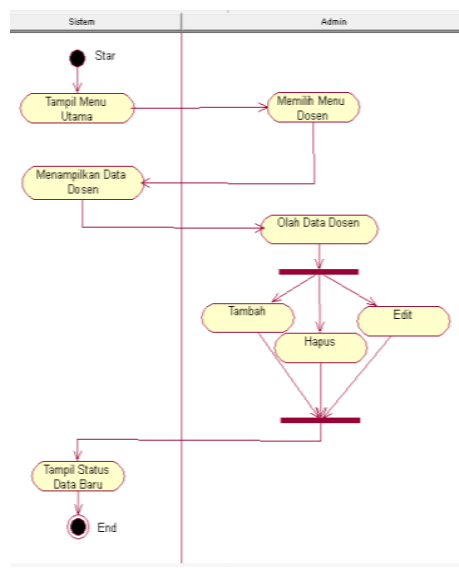

Figure 3. Lecturer Data Process

From Figure 3. Explains that the admin chooses the lecturer menu, and the system will display it, then the Admin can process the data after stored data and will be displayed on the lecturer page. 


\subsubsection{Activity Diagram of Research Data Process}

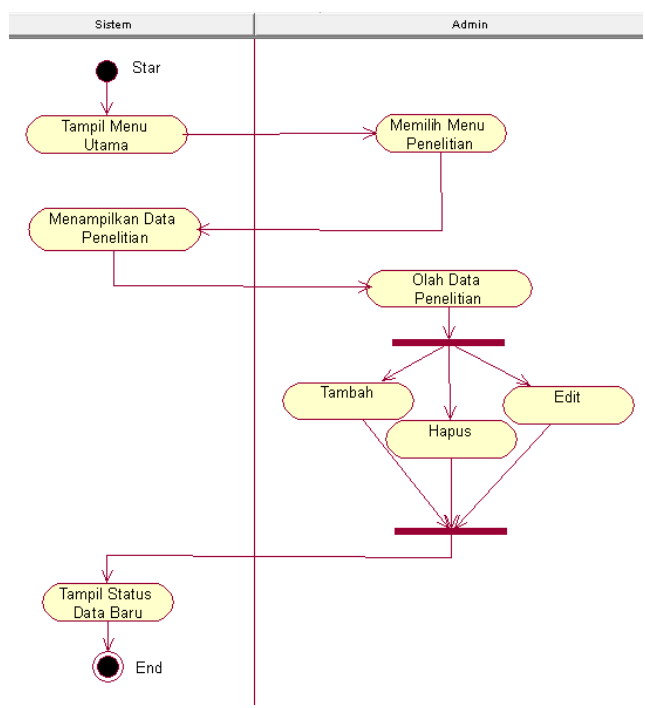

Figure 4. Research Data Process

From Figure 4. Explains that the admin chooses the research menu, and the system will display it, then Admin can process the data after stored data and will be displayed on the research page.

\subsubsection{Activity Diagram of Community Service Process}

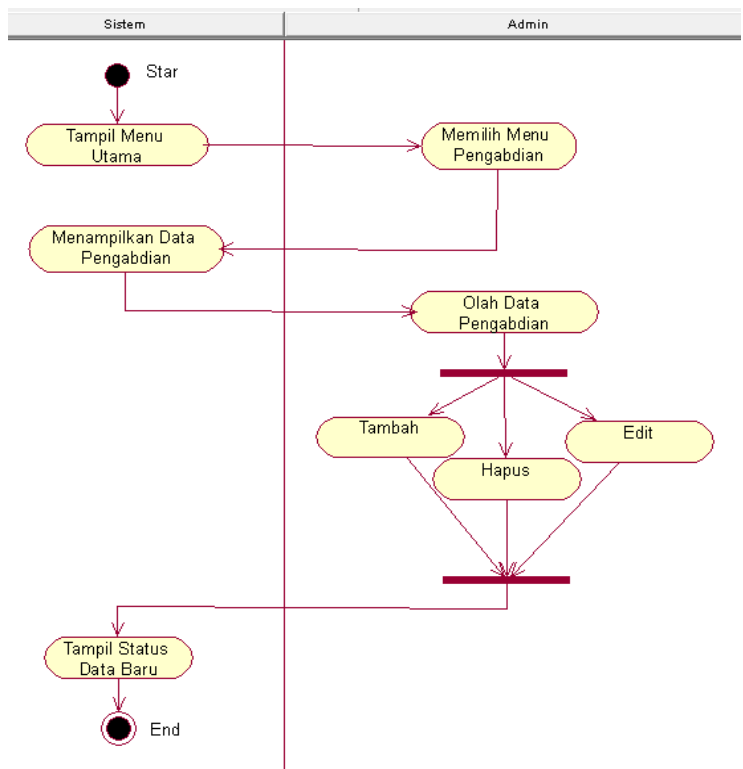

Figure 5. Comunity Service Data Process

From Figure 5. Explains that the admin chooses the community service menu and the system will display it, then the admin can process the data after stored data and will be displayed on the community service page.

\subsection{Class Diagram}

Figure 6 shows the association relationship of each class in the information system management of research and community service at P3-M Uniyap. 


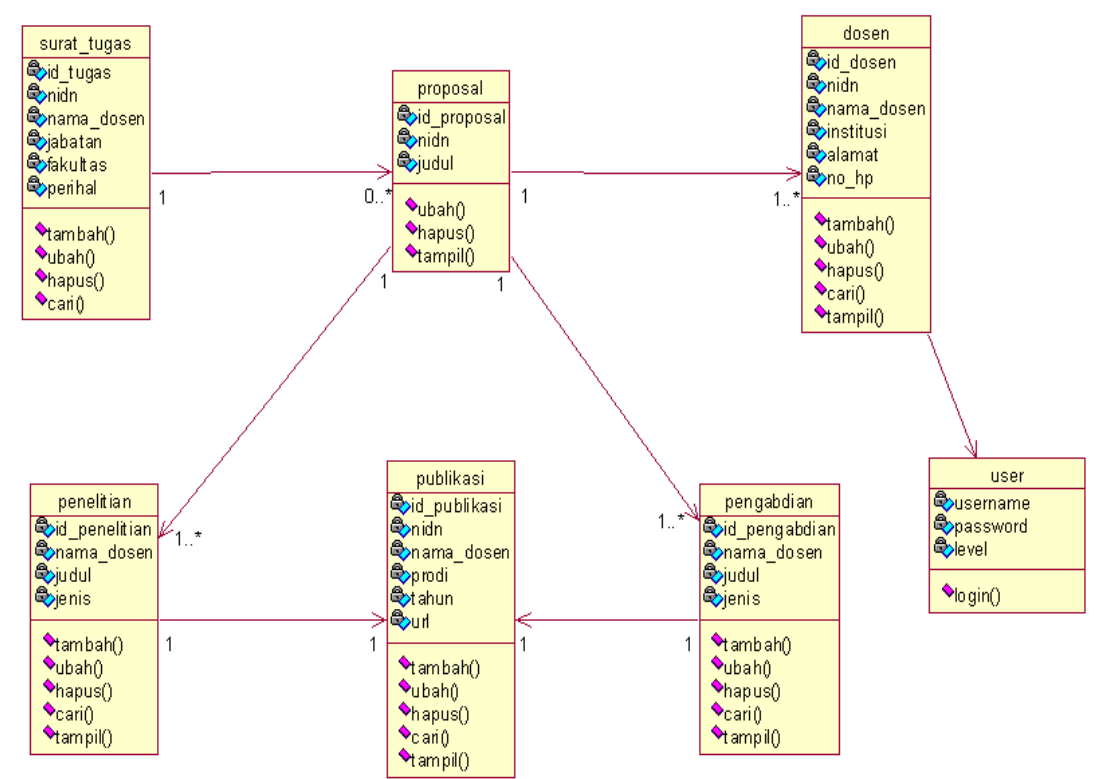

Figure 6. Class Diagram

From Figure 6. Explains the class diagram shown the proposal table is connected to the assignment letter table, lecturer table, research table, community service table and publications. While the user table is connected to the lecturer table.

\subsection{ERD}

Figure 7 is the Figure of the Entity Relation Diagram on the research and community service management information system at Uniyap.

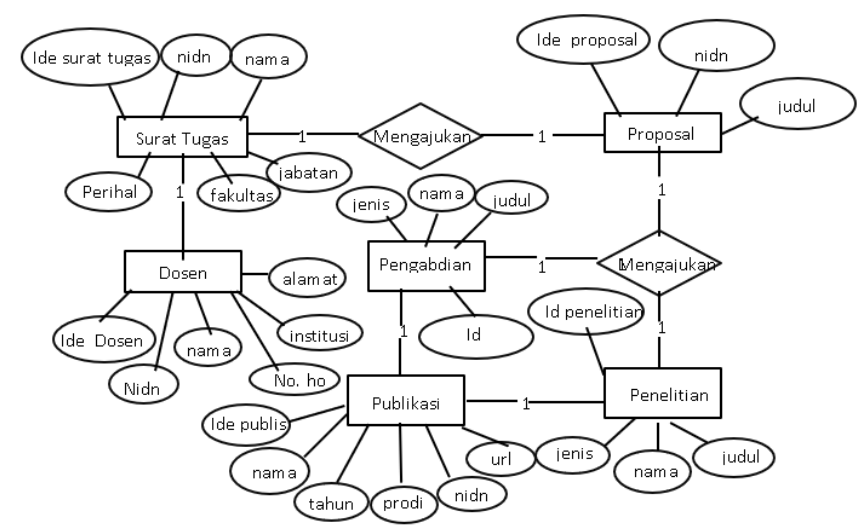

Figure 7. ERD Information System LP2M Process

From Figure 7. Explains the relationship between entities, they are the letter of assignment entity, and the proposal entity is one to one. The relationship between the lecturer entity and the assignment letter entity is one to one. The relationship between the proposal entity and the service entity is one to one. The relationship between the proposal entity and the research entity is one to one.

\subsection{Interface Design}

\subsubsection{Admin Interface Page}

From Figure 8. Explains the admin Dashboard interface design after login which consists of Dashboard menu, it displays research and community service information in the graphs form. And lecturer data menu, it displays assignment letter menu, research menu, service menu, and publication menu. 


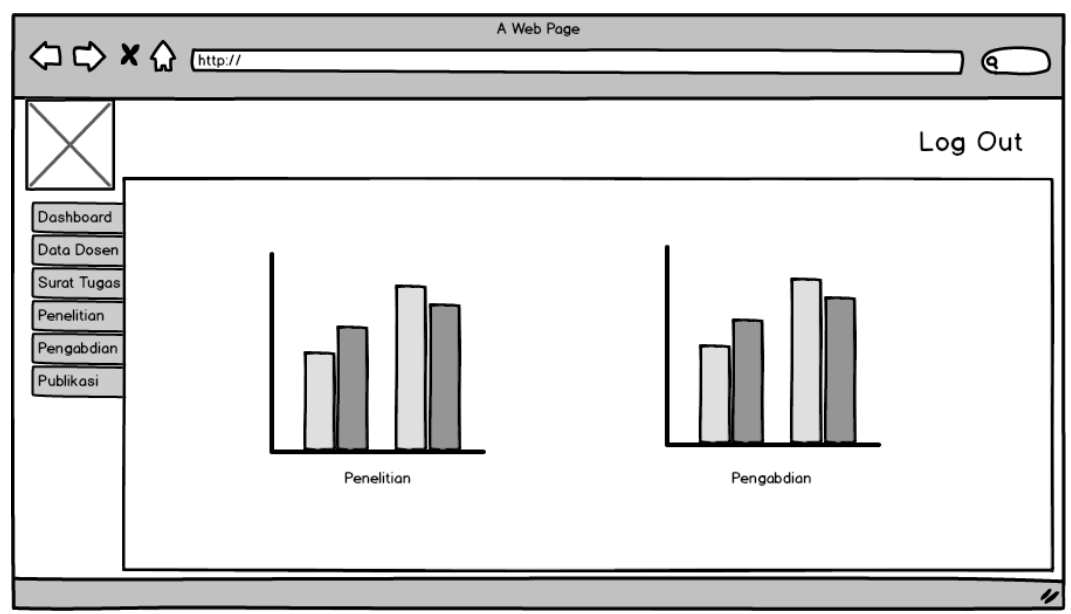

Figure 8. Admin Interface Page

\subsubsection{Proposal Validation Interface Page}

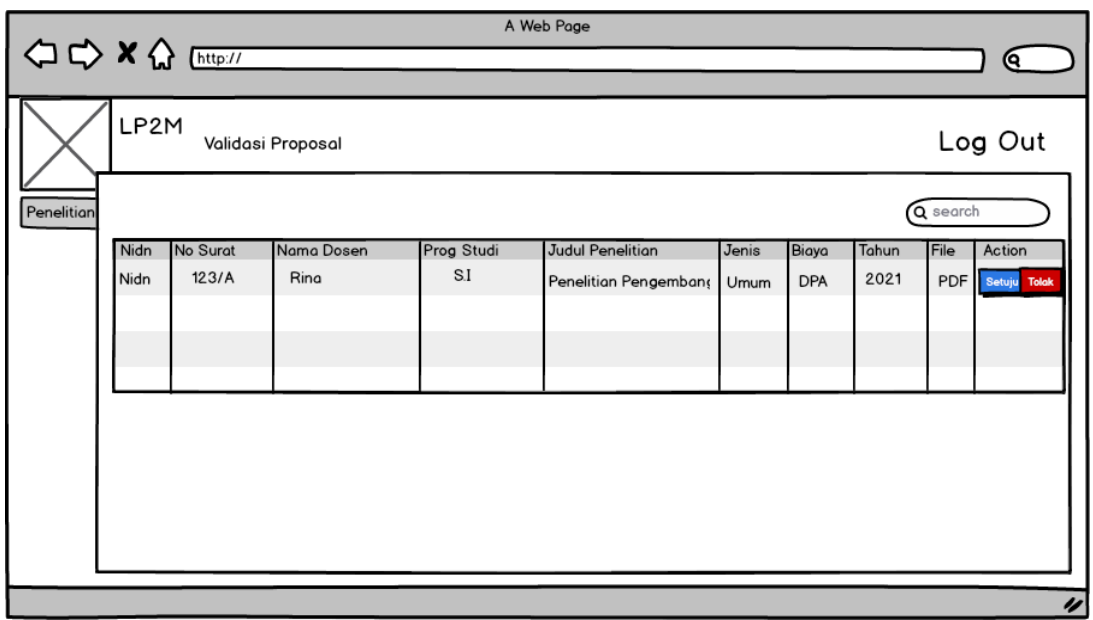

Figure 9. Proposal Validation Interface page

\section{Results and Discussion}

After the design phase, the following are the results of several menus in the interface page.

\subsection{Login Page View}

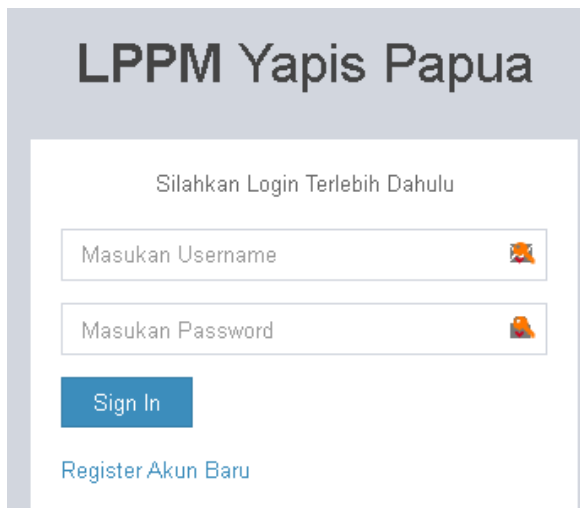

Figure 10. Login Page View

From Figure 10. Explains about fill the username (NIDN) and password to enter the admin page or lecturer page. 


\subsection{Admin Main Menu Page View}

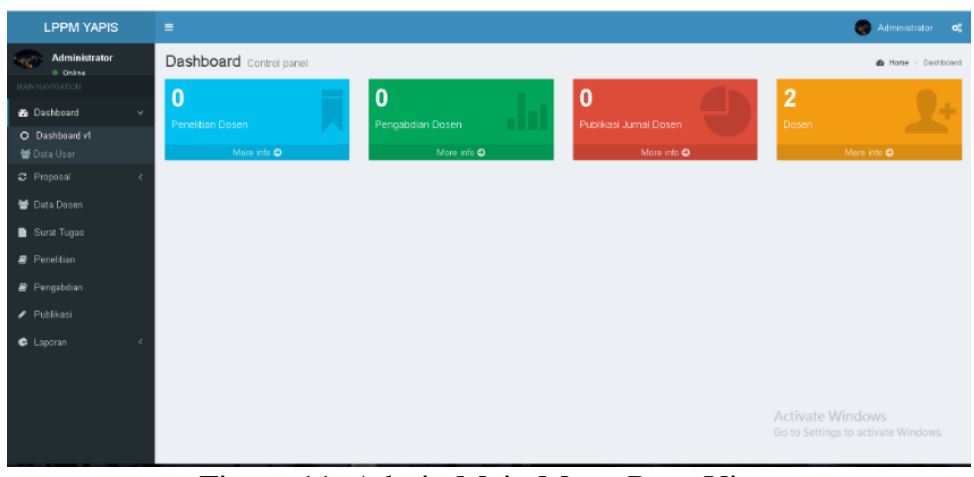

Figure 11. Admin Main Menu Page View

From Figure 11. Explains the display of the admin main page after login, it contains the proposal menu, lecturer data menu, assignment letter menu, research menu, service menu, publication menu and report menu.

\subsection{Research Upload Page View}

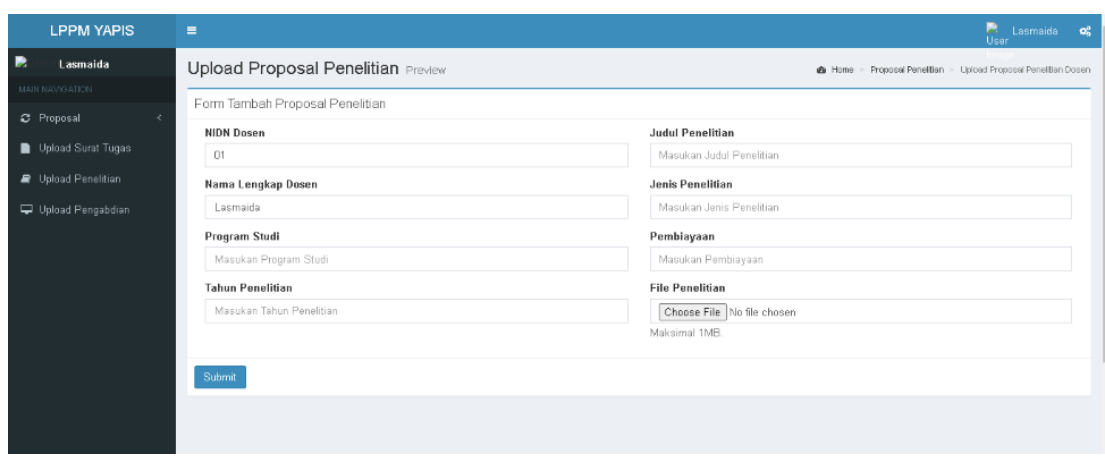

Figure 12. Research upload View

From Figure 12. Explains the research upload form which contains the lecturer's ID, full name of the lecturer, study program, year of research, title of research, type of research, funding and research files.

\subsection{Community Service Upload Form Page View}

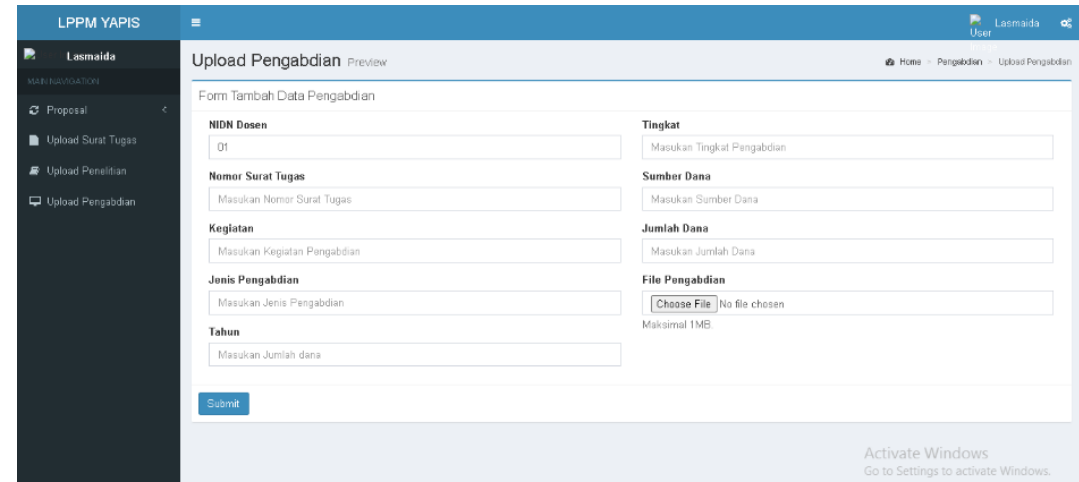

Figure 13. Comunity Service Page Upload View

From Figure 13. Explains about uploading community service which contains lecturer ID, assignment letter number, activities, type of service, year, level, source of funds, amount of funds, and community service files. 


\section{References}

[1] R. Agustino, Y. B. Widodo, A. Wiyatno, and M. I. Saputro, "Sistem Informasi Penelitian dan Pengabdian Masyarakat di Universitas Mohammad Husni Thamrin," J. Jaring SainTek, vol. 2, no. 1, pp. 1-12, 2020, doi: 10.31599/jaring-saintek.v2i1.61.

[2] D. Ratnasari and A. Tawakal, "Analisis Dan Perancangan Aplikasi Sistem Informasi Penelitian Dan Pengabdian Masyarakat Lppm Stt Terpadu Nurul Fikri," Nurul Fikri, 2017.

[3] S. Handayani, "Rancang Bangun Sistem Informasi Penelitian dan Pengabdian Dosen Fakultas Teknologi Informasi dan Komunikasi (FTIK) Universitas Semarang (USM),” Infokam, vol. 13, no. 1, pp. 11-22, 2017, [Online]. Available: http://amikjtc.com/jurnal/index.php/jurnal/article/view/116.

[4] \& M. Melyanti, R., Iqbal, M., "Sistem Informasi Manajemen Penelitian Dan Pengabdian Masyarakat Di Bagian P3M (Studi Kasus: Stmik Hang Tuah Pekanbaru)," J. Ilmu Komput., vol. 9, no. 2, pp. 165-176, 2020, [Online]. Available: http://jik.htp.ac.id.

[5] H. Hamzah, "Sistem Informasi Kegiatan Penelitian dan Pengabdian Kepada Masyarakat Universitas Respati Yogyakarta," J. Nas. Teknol. dan Sist. Inf., vol. 2, no. 2, pp. 17-26, 2016, doi: 10.25077/teknosi.v2i2.2016.17-26.

[6] G. B. Putra, "Rancang Bangun Sistem Penelitian Dan Pengabdian Masyarakat Universitas Bangka Belitung Berbasis Web Server," J. ECOTIPE, vol. 4, no. 1, pp. 17-22, 2017, doi: 10.33019/ecotipe.v4i1.14. 